\title{
Chloroplast genome sequence of Chongming lima bean (Phaseolus lunatus L.) and comparative analyses with other legume chloroplast genomes
}

\author{
Shoubo Tian ${ }^{1 \dagger}$, Panling $\mathrm{Lu}^{1 \dagger}$, Zhaohui Zhang ${ }^{1}$, Jian Qiang Wu², Hui Zhang ${ }^{1 *}$ and Haibin Shen ${ }^{1 *}$
}

\begin{abstract}
Background: Lima bean (Phaseolus lunatus L.) is a member of subfamily Phaseolinae belonging to the family Leguminosae and an important source of plant proteins for the human diet. As we all know, lima beans have important economic value and great diversity. However, our knowledge of the chloroplast genome level of lima beans is limited.

Results: The chloroplast genome of lima bean was obtained by Illumina sequencing technology for the first time. The Cp genome with a length of 150,902 bp, including a pair of inverted repeats (IRA and IRB 26543 bp each), a large single-copy (LSC 80218 bp) and a small single-copy region (SSC 17598 bp). In total, 124 unique genes including 82 protein-coding genes, 34 tRNA genes, and 8 rRNA genes were identified in the P. lunatus Cp genome. A total of 61 long repeats and 290 SSRs were detected in the lima bean Cp genome. It has a typical 50 kb inversion of the Leguminosae family and an $70 \mathrm{~kb}$ inversion to subtribe Phaseolinae. rp/16, accD, petB, rsp 16, clpP, ndhA, ndhF and $y c f 1$ genes in coding regions was found significant variation, the intergenic regions of trnk-rbcL, rbcL-atpB, ndhJrps4, psbD-rpoB, atpl-atpA, atpA-accD, accD-psbJ, psbE-psbB, rsp11-rsp19, ndhF-ccsA was found in a high degree of divergence. A phylogenetic analysis showed that $P$. lunatus appears to be more closely related to $P$. vulgaris, V.unguiculata and V. radiata.
\end{abstract}

Conclusions: The characteristics of the lima bean Cp genome was identified for the first time, these results will provide useful insights for species identification, evolutionary studies and molecular biology research.

Keywords: Phaseolus lunatus, Chloroplast genome, Leguminosae, Phylogenetic relationship, Comparative analysis

\section{Background}

Lima bean (Phaseolus lunatus L.) is one of five species domesticated within Phaseolus, together with common bean (P. vulgaris L.), scarlet runner bean (P. coccineus L.), tepary bean (P. acutifolius A. Gray) and year bean

\footnotetext{
*Correspondence: zhanghui@saas.sh.cn; shb8311@163.com

†Shoubo Tian and Panling Lu contributed equally to this work.

IShanghai Key Laboratory of Protected Horticultural Technology, Horticultural Research Institute, Shanghai Academy of Agricultural Sciences, Shanghai 201403, China

Full list of author information is available at the end of the article
}

(P. polyanthus Greenm) [1]. Lima beans play an important role in the human diet as an important source of protein when common beans do not grow well in warmer and drier regions [2]. Wild lima bean have three gene pools, two Mesoamerican pools (MI and MII) and the Andean pool (AI) [3]. Lima bean is a self-compatible annual or short living perennial and predominantly selfpollinating species with a mixed-mating system, it was used as a plant model due to its alternating outbreederinbreederbehavior $[4,5]$. The cultivated form is widely

(c) The Author(s). 2021 Open Access This article is licensed under a Creative Commons Attribution 4.0 International License, which permits use, sharing, adaptation, distribution and reproduction in any medium or format, as long as you give appropriate credit to the original author(s) and the source, provide a link to the Creative Commons licence, and indicate if changes were made. The images or other third party material in this article are included in the article's Creative Commons licence, unless indicated otherwise in a credit line to the material. If material is not included in the article's Creative Commons licence and your intended use is not permitted by statutory regulation or exceeds the permitted use, you will need to obtain permission directly from the copyright holder. To view a copy of this licence, visit http://creativecommons.org/licenses/by/4.0/. The Creative Commons Public Domain Dedication waiver (http://creativecommons.org/publicdomain/zero/1.0/) applies to the data made available in this article, unless otherwise stated in a credit line to the data. 
distributed all over the world, Chongming lima bean, an important characteristic vegetable variety in the Chongming area, has been grown on Chongming Island for more than 100 years [6].

Chloroplasts, a place for plant photosynthesis, starch, fatty acids and amino acids biosynthesis, play an important role in the transfer and expression of genetic material [7]. Chloroplast has its own genome, chloroplast genome of most plants are mostly double-stranded circular, but a few species have linear forms with multiple copies. The genome size usually ranges from 120 to 170 $\mathrm{kb}$ and includes 120-130 genes [8]. It has a typical quarter structure, which composed of a large single-copy region, a small single-copy region and a pair of large inverted repeats [9-11]. The Cp genome is highly conserved, the differences between different plant species are mainly caused by the IR region's contraction and expansion $[12,13]$. With the development of highthroughput sequencing technologies, there were more than 2400 plant $\mathrm{Cp}$ genomes have been published in the NCBI database [14]. Leguminosae, with nearly 770 genera and more than 19,500 species, is the third largest family of angiosperms [15]. Within the Leguminosae family, there were more than 44 species $\mathrm{Cp}$ genomes have been published including C. arietinum [8], G. gracilis [16], L. japonica [17], C. tetragonoloba [18], G. max [19], $V$. radiate [20], and $P$. vulgaris [21]. Leguminosae has experienced a great number of plastid genomic rearrangements [22], including loss of one copy of the IR $[23,24]$, inversion of $50 \mathrm{~kb}$ and $70 \mathrm{~kb}[17,21,25]$, transfer of infA, rpl22 and $a c c D$ genes to the nucleus [26-28] and loss of the rps12 and clpP introns $[8,26]$.

Chloroplast DNA has been extensively used to taxonomy, phylogenetics and evolution of plants, due to its low substitution rates of nucleotide and relatively conserved structural variation of genomic [29-31]. Phylogenetic analyses of Leguminosae were mainly based on gene fragments in chloroplast DNA like trnL, rbcL and matK [32-34]. Based on the chloroplast matk gene and combining the characteristics of morphology, chemistry and chromosome number, a new classification system of six subfamilies was proposed, and the most complete leguminous phylogeny tree was constructed so far [15]. However, the classification and phylogenetic relationships of the main branches within the subfamilies are still unclear. Chloroplast phylogenetic genome has been successfully used to analyze the phylogenetic relationship of many difficult groups, and it also provided a better system framework for studying the structural characteristics, variation and evolution of plants $[35,36]$. Due to the limited chloroplast genomes of legumes that have been sequenced, phylogenetic chloroplast phylogeny has not been applied to classification of the Leguminosae.
Currently, there are no published studies of the $\mathrm{Cp}$ genome of lima bean. In this study, we applied a combination of de novo and reference-guides to assemble complete $\mathrm{Cp}$ genome sequence of $P$. lunatus. Here, we not only described the whole $\mathrm{Cp}$ genome sequence of $P$. lunatus and the characteristics of long repeats and SSRs, but also compared and analysed the $\mathrm{Cp}$ genome with other members of Leguminosae. It is expected that the results will help us to understand of the $\mathrm{Cp}$ genome of lima bean and provide markers for phylogenetic and genetic studies.

\section{Results}

Characteristics of the $P$. lunatus L. Cp genome

The Cp genome of lima bean was $150,902 \mathrm{bp}$ in size with a typical quadripartite structure, containing a pair of inverted repeats (IRs; 26,543 bp), a large single copy (LSC; 80,218 bp) and a small single copy (SSC; 17,598 bp) (Fig. 1). The GC content in lima bean was $35.44 \%$, the GC content of LSC, SSC and IR regions was 32.92, 28.61 and $41.52 \%$ respectively (Table 1 ), IR regions was higher than the LSC and SSC regions. Species of Leguminous: G. max, P. vulgaris, V. unguiculata, G. sojasieb, V. faba and P. sativum were selected to Compare with lima bean (Table 2). Although the sizes of the overall genome had differences, the GC content was similar in each region (LSC, SSC and IR) of different species. There is a litter difference in total genes, CDS and tRNAs among the seven species. C. cajan has most genes, CDS and tRNAs and $V$. radiata has least.

There were 129 genes found in the P. lunatus Cp genome, containing 82 protein-coding genes, 37 tRNA genes, 8 rRNA genes and 2 pseudogenes (Tables 2 and 3). There are 79 genes (56 protein-coding and 23 tRNAs) located in LSC region and 13 genes (12 CDS and 1tRNA) in SSC region. Among them, 35 genes (13 CDS, 14 tRNAs and 8 rRNAs genes) were duplicated in the IR regions (Fig. 1; Table S1). Codon usage frequency of the $P$. lunatus $\mathrm{Cp}$ genome was estimated and summarized (Table S2). Totally, all the genes are encoded by 25,873 codons, in these codons, the most frequent amino acids are leucine $(2719,10.51 \%)$ and the least are cysteine (300, $1.16 \%)$. The most preferred synonymous codons end with $\mathrm{A}$ and $\mathrm{U}$.

Overall, 22 intron-containing genes (14 protein-coding genes and 8 tRNA genes) were found (Table 4). Among them, 20 genes have one intron, $y c f 3$ and $c l p P$ have two introns. trnL-UAA and trnK-UUU have the the smallest intron (467 bp) and largest intron (2562 bp), respectively. In the $P$. lunatus $\mathrm{Cp}$ genome, rps16 and rpl133 gene was found to be present as a pseudogene. 


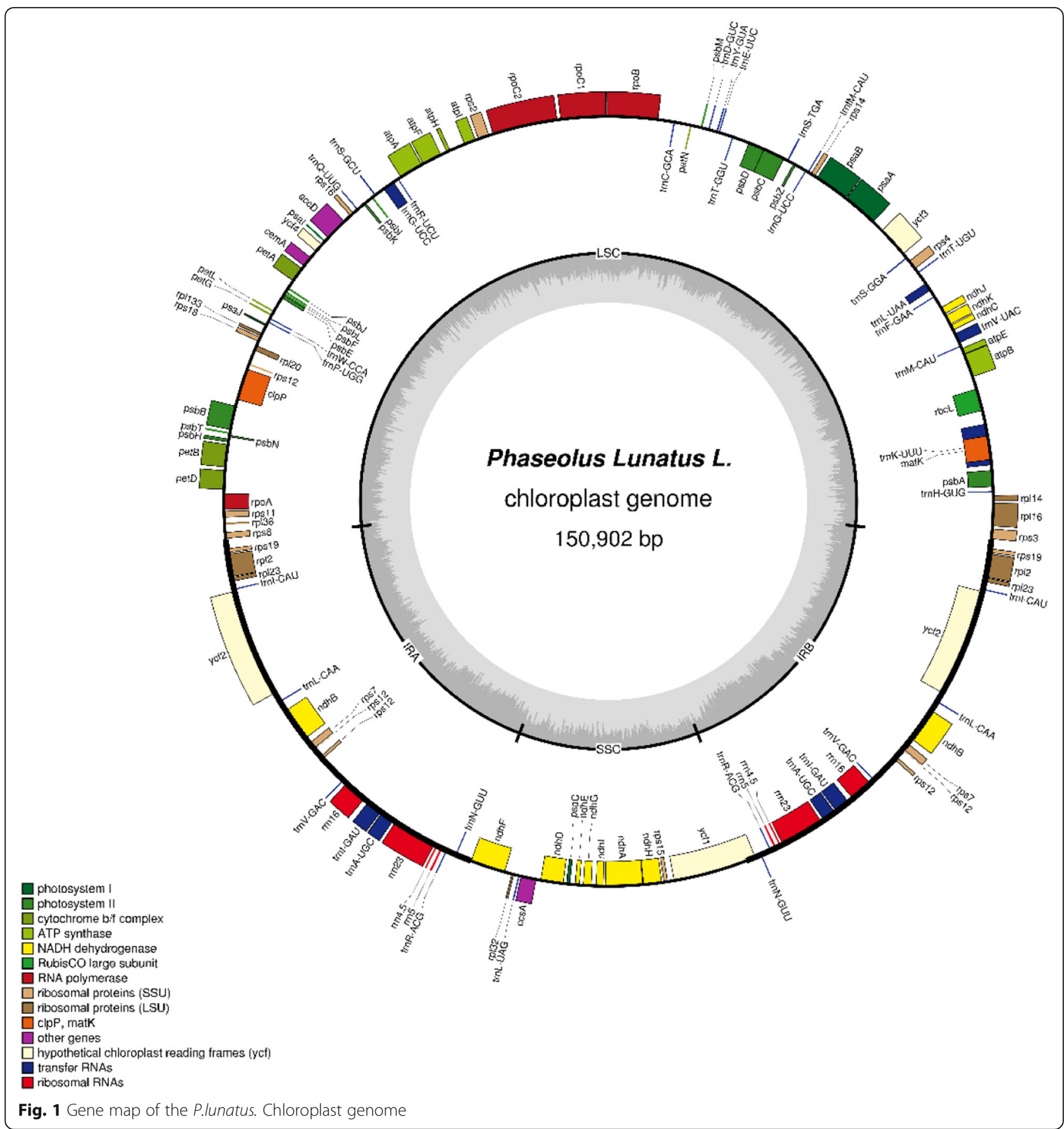

Table 1 Base composition of the P.lunatus. Chloroplast genome

\begin{tabular}{lllllll}
\hline Region & $\mathbf{A}(\%)$ & $\mathbf{C}(\%)$ & $\mathbf{G}(\%)$ & $\mathbf{T}(\mathbf{U})(\%)$ & $\mathbf{A}+\mathbf{T}(\%)$ & $\mathbf{G}+\mathbf{C}(\%)$ \\
\hline LSC & 33.87 & 15.97 & 16.95 & 33.22 & 67.09 & 32.92 \\
SSC & 35.36 & 15.19 & 13.42 & 36.03 & 71.39 & 28.61 \\
IRa & 29.47 & 21.55 & 19.98 & 29.01 & 58.48 & 41.53 \\
IRb & 29.01 & 19.98 & 21.55 & 29.47 & 58.48 & 41.53 \\
Total & 32.41 & 17.56 & 17.88 & 32.15 & 64.56 & 35.44 \\
\hline
\end{tabular}

\section{Long repeats and SSRs}

The analysis of long-repeat in the P. lunatus showed 33 palindromic repeats, 19 forward repeats, 6 reverse repeats and 3 complement repeats. Among them, 46 repeats were $30-39 \mathrm{bp}$ in length, 8 repeats were $40-49 \mathrm{bp}$, 7 repeats were more than $50 \mathrm{bp}$, and the longest repeat was $287 \mathrm{bp}$ in length and was located in the IR region (Fig. 2; Table S3). Most repeats were located in the intron sequences and intergenic spacer (IGS), and the minority were found in the $y c f 2, r p l 16, n d h A, y c f 3, p s b L$, 
Table 2 Comparison analyses of Cp genomes among six Leguminosae species

\begin{tabular}{llllllllll}
\hline Species & $\begin{array}{l}\text { Genome size } \\
\text { (bp) }\end{array}$ & $\begin{array}{l}\text { LSC } \\
(\mathbf{b p})\end{array}$ & $\begin{array}{l}\text { SSC } \\
\text { (bp) }\end{array}$ & $\begin{array}{l}\text { IR } \\
(\mathbf{b p})\end{array}$ & $\begin{array}{l}\text { Number of } \\
\text { genes }\end{array}$ & $\begin{array}{l}\text { Protein-coding genes } \\
\text { (CDS) }\end{array}$ & $\begin{array}{l}\text { tRNA } \\
\text { genes }\end{array}$ & $\begin{array}{l}\text { rRNA } \\
\text { genes }\end{array}$ & $\begin{array}{l}\text { GC } \\
\text { content(\%) }\end{array}$ \\
\hline C. cajan & 152,242 & 83,369 & 17,815 & 25,529 & 134 & 87 & 39 & 8 & 34.97 \\
G. max & 152,218 & 83,175 & 17,895 & 25,574 & 128 & 83 & 37 & 8 & 35.37 \\
G. soja & 152,217 & 83,174 & 17,895 & 25,574 & 129 & 83 & 38 & 8 & 35.38 \\
P. lunatus. & 150,902 & 80,218 & 17,598 & 26,543 & 127 & 82 & 37 & 8 & 35.44 \\
P. vulgaris & 150,285 & 79,823 & 17,610 & 26,426 & 127 & 83 & 36 & 8 & 35.44 \\
V. radiata & 151,271 & 80,898 & 17,425 & 26,474 & 126 & 82 & 36 & 8 & 35.23 \\
V. & 152,415 & 81,822 & 17,425 & 26,584 & 130 & 84 & 38 & 8 & 35.24 \\
unguiculata & & & & & & & & &
\end{tabular}

psaA, psaB, trnS-GGA, trnT-UGU, trnS-GCU, trnS-TGA, trnT-GGU, ndhF, trnS-GCU and trnK-UUU genes.

Two hundred ninety SSRs were identified in $P$. lunatus, containing 203 mononucleotides, 21 dinucleotides, 56 trinucleotides, and 10 tetranucleotides (Fig. 3; Table S4). Among these SSRs, most distributed in LSC (63.45\%) followed by SSC (22.76\%) and IRs (13.79\%), whereas 133 were located in intergenic spacers, 43 in introns and 114 in extrons, SSRs in genes including $n d h B A \backslash D E \backslash H F, y c f 1-4, \quad r p l 1416 \backslash 32133, \operatorname{ccs} A, \operatorname{atp} B \backslash F \backslash$, cemA, clpP, PetD $\backslash B \backslash A, \quad p s a T \backslash B \backslash C A, \quad r b c L, \quad r p 12 \backslash 132$, rро $A \backslash B \backslash C 1 \backslash C 2, \quad$ rps $2 \backslash 14 \backslash 15 \backslash 18 \backslash 19, \quad$ rrn23, $\quad$ trnK-UUU
(intron)/matK, trnK-UUU, trnV-UAC, trnG-UCC and trnI-GAU.

\section{Gene order}

The Cp genome structures of eight-sequenced legumes were selected and compared with lima bean using Mauve software, with the of $A$. thaliana as a reference (Fig. 4). All the legume have almost the same gene order, and the $\mathrm{Cp}$ genomes of $C$. arietinum and $M$. truncatula have lost one copy of the IR. on comparison with Arabidopsis, all have a common 50-kb inversion, spanning from $r b c L$ to rps16 gene in the LSC region. The Cp

Table 3 The genes present in the P.lunatus

\begin{tabular}{|c|c|c|}
\hline Category & Gene group & Gene name \\
\hline \multirow[t]{6}{*}{ Photosynthesis } & Subunits of photosystem I & psaA, psaB, psaC, psal, psaJ \\
\hline & Subunits of photosystem ॥ & $p s b A, p s b B, p s b C, p s b D, p s b E, p s b F, p s b H, p s b l, p s b J, p s b K, p s b L, p s b M, p s b N, p s b T, p s b Z$ \\
\hline & $\begin{array}{l}\text { Subunits of NADH } \\
\text { dehydrogenase }\end{array}$ & $n d h A^{*}, n d h B^{*}(2), n d h C, n d h D, n d h E, n d h F, n d h G, n d h H, n d h l, n d h J, n d h K$ \\
\hline & $\begin{array}{l}\text { Subunits of cytochrome b/f } \\
\text { complex }\end{array}$ & pet $A$, pet $B^{*}$, pet $D^{*}$, petG, petL, petN \\
\hline & Subunits of ATP synthase & $\operatorname{atp} A, \operatorname{atp} B, \operatorname{atp} E, \operatorname{atpF} F^{*}, \operatorname{atpH}$, atpl \\
\hline & Large subunit of rubisco & $r b c L$ \\
\hline \multirow[t]{5}{*}{ Self-replication } & $\begin{array}{l}\text { Proteins of large ribosomal } \\
\text { subunit }\end{array}$ & \#rpl133, rp/14, rp/16*, rp/2* (2), rp/20, rpl23 (2), rp/32, rp/36 \\
\hline & $\begin{array}{l}\text { Proteins of small ribosomal } \\
\text { subunit }\end{array}$ & \#rps16, rps11, rps12**(2), rps14, rps15, rps18, rps19 (2), rps2, rps3, rps4, rps7 (2), rps8 \\
\hline & $\begin{array}{l}\text { Subunits of RNA } \\
\text { polymerase }\end{array}$ & rpoA, rpoB, rpoC1*, rpoC2 \\
\hline & Ribosomal RNAs & $r r n 16(2), r r n 23(20, r r n 4.5(2), r r n 5(2)$ \\
\hline & Transfer RNAs & 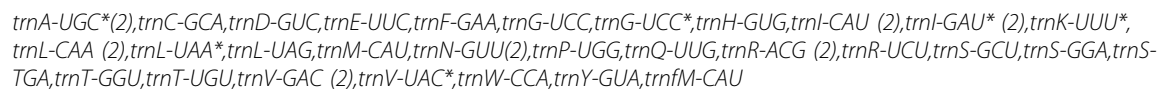 \\
\hline \multirow[t]{5}{*}{ Other genes } & Maturase & matK \\
\hline & Protease & $c l p P^{* *}$ \\
\hline & $\begin{array}{l}\text { Envelope membrane } \\
\text { protein }\end{array}$ & cemA \\
\hline & Acetyl-CoA carboxylase & $a c c D$ \\
\hline & $\begin{array}{l}\text { c-type cytochrome } \\
\text { synthesis gene }\end{array}$ & $\operatorname{cCs} A$ \\
\hline $\begin{array}{l}\text { Genes of unknown } \\
\text { function }\end{array}$ & $\begin{array}{l}\text { Conserved hypothetical } \\
\text { chloroplast ORF }\end{array}$ & $y c f 1, y c f 2(2), y c f 3^{* *}, y c f 4$ \\
\hline
\end{tabular}

Notes: Gene*: Gene with one intron; Gene**: Gene with two introns; \#Gene: Pseudo gene; Gene (2): Number of copies of multi-copy genes; 
Table 4 The lengths of exons and introns in genes with introns in the P. lunatus. Chloroplast genome

\begin{tabular}{|c|c|c|c|c|c|c|}
\hline Gene & Location & Exon I (bp) & Intron I (bp) & Exon II (bp) & Intron II (bp) & Exon III (bp) \\
\hline$r p / 16$ & LSC & 9 & 1036 & 402 & & \\
\hline $\operatorname{trnK-UUU}$ & LSC & 37 & 2562 & 35 & & \\
\hline $\operatorname{trn} V-U A C$ & LSC & 38 & 576 & 37 & & \\
\hline $\operatorname{trn} L-U A A$ & LSC & 37 & 467 & 50 & & \\
\hline ycf3 & LSC & 129 & 683 & 228 & 797 & 153 \\
\hline rpoct & LSC & 435 & 812 & 1620 & & \\
\hline $\operatorname{atpF}$ & LSC & 144 & 730 & 399 & & \\
\hline $\operatorname{trnG}$ UCC & LSC & 23 & 694 & 49 & & \\
\hline rps 12 & IRa & 114 & - & 231 & 534 & 24 \\
\hline$c l p P$ & LSC & 68 & 741 & 297 & 716 & 223 \\
\hline petB & LSC & 6 & 792 & 642 & & \\
\hline petD & LSC & 9 & 717 & 474 & & \\
\hline$r p / 2$ & $\mathrm{IRb}$ & 393 & 616 & 471 & & \\
\hline$n d h B$ & $\mathrm{IRb}$ & 723 & 691 & 756 & & \\
\hline$r p s 12$ & $\mathrm{IRb}$ & 231 & - & 24 & 534 & 114 \\
\hline $\operatorname{trn} l-G A U$ & $\mathrm{IRb}$ & 42 & 935 & 35 & & \\
\hline $\operatorname{trnA-UGC}$ & $\mathrm{IRb}$ & 38 & 811 & 35 & & \\
\hline$n d h A$ & SSC & 552 & 1292 & 540 & & \\
\hline $\operatorname{trn} A-U G C$ & IRa & 38 & 811 & 35 & & \\
\hline $\operatorname{trn} 1-G A U$ & IRa & 42 & 935 & 35 & & \\
\hline$n d h B$ & IRa & 723 & 691 & 756 & & \\
\hline$r p / 2$ & IRa & 393 & 616 & 471 & & \\
\hline
\end{tabular}

genomes of $P$. lunatus, $P$. vulgaris, $V$. radiata and $V$. unguicalata have $70 \mathrm{~kb}$ inversion to subtribe Phaseolinae but are not found in other Cp genomes. G soja, M. truncatula and $C$. arietinum share the same gene order with $C$. cajan, G. $\max$ and $G$ soja except for the loss of the IRb region.

\section{Comparison of complete chloroplast genomes among Leguminosae species}

To verify the possibility of genome divergence, mVISTA was used to compare the Phaseolinae $\mathrm{Cp}$ genomes, using annotations of lima bean as a reference (Fig. 5). The result shows high sequence identity with Phaseolinae

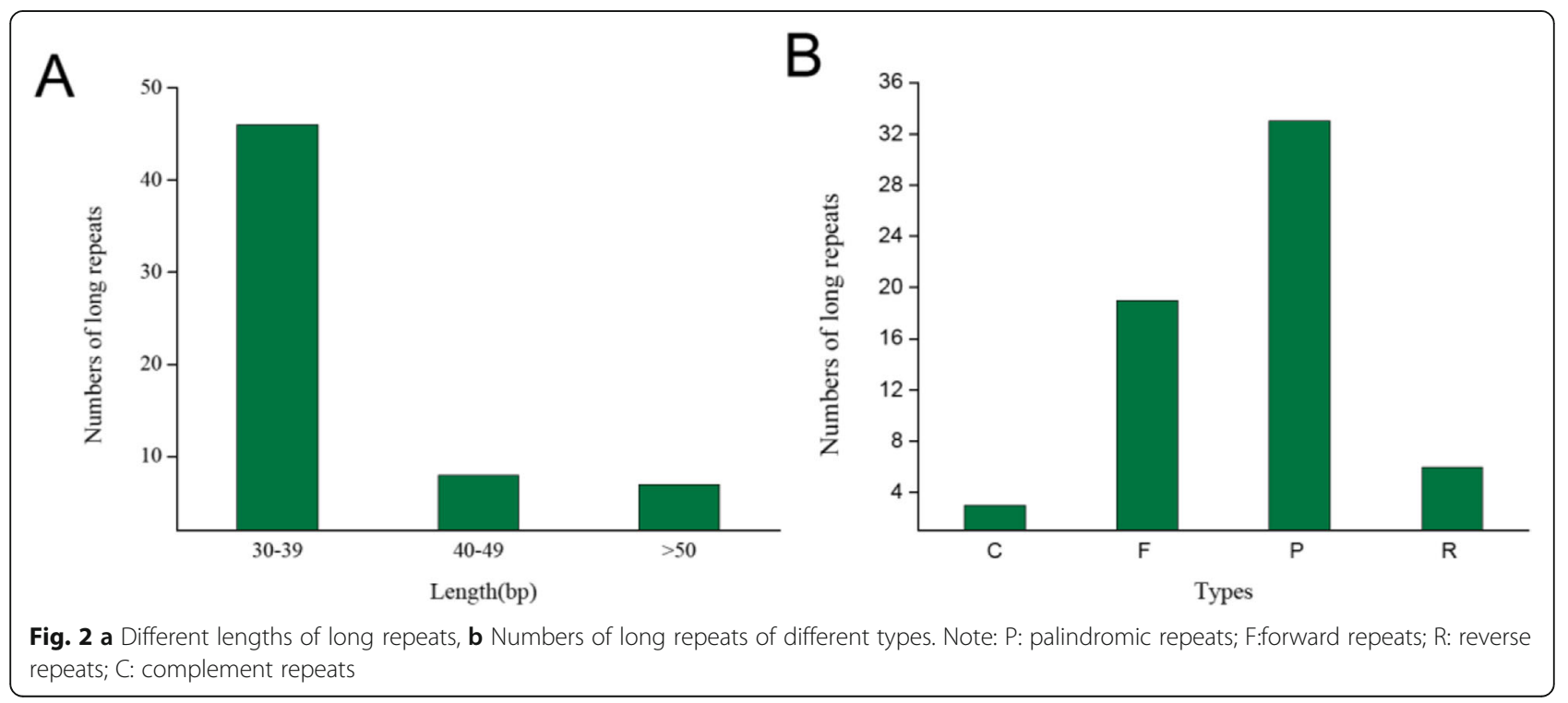



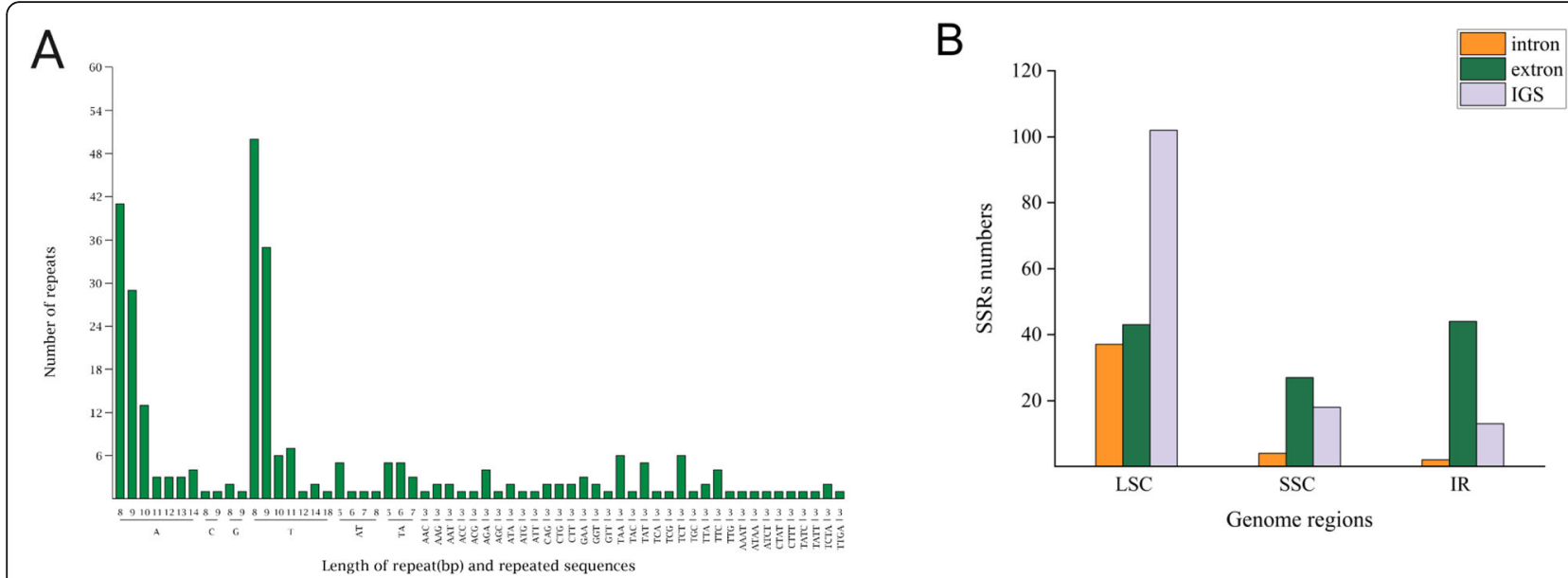

Fig. 3 a Types and numbers of simple sequence repeats (SSRs) and $\mathbf{b}$ Simple sequence repeats (SSRs) distribution in different regions

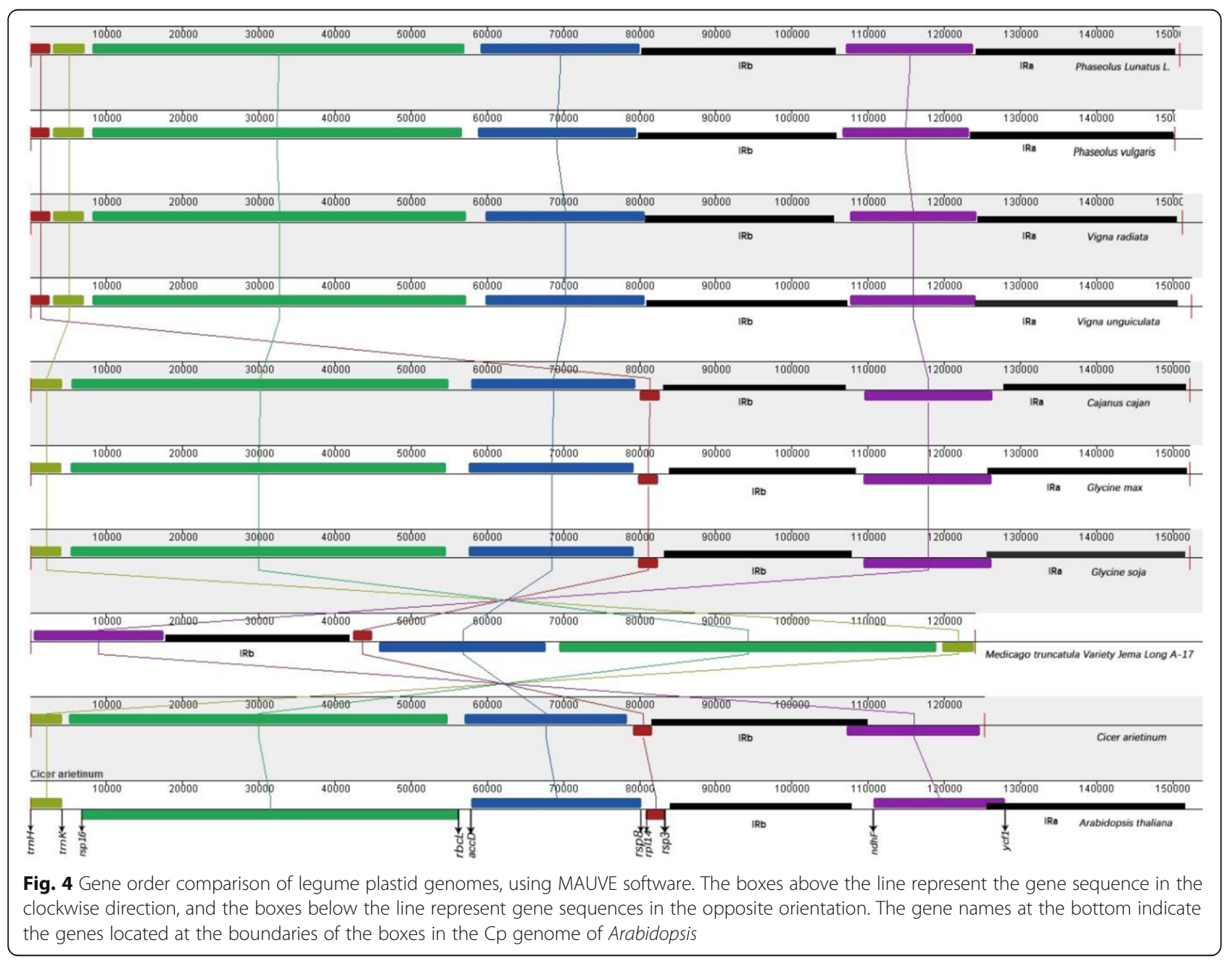


species. $r p l 16, a c c D$, petB, rsp16, clpP, ndhA, ndhF and $y c f 1$ genes in coding regions was found with significant variation, trnk-rbcL, $r b c L-a t p B, n d h J-r p s 4, p s b D-r p o B$, atpI-atpA, atpA-accD, accD-psbJ, psbE-psbB, rsp11rsp19, ndhF-ccs $A$ in the intergenic regions were identified with a high degree of divergence .

A comparison of the boundaries of the lima bean $\mathrm{Cp}$ genome was performed among the other six Leguminosae species: $P$. vulgaris, $V$. radiata, $V$. unguiculata, C. cajan, G.max, and G. soja (Fig. 6). At the LSC/IR junction of lima bean, the rps19 and trnN genes are duplicated at the IR/SSC junction completely and included in the IR region. a partial $y c f 1$ gene is included at the IRa/SSC junction. Compared to other species in the genus, the range of each region showed substantial differences. The rps19 gene in the $P$. lunatus, $P$. vulgaris, $V$. radiate $C \mathrm{p}$ genomes was shifted by $564 \mathrm{bp}$ from IR to LSC at the LSC/IR border and $701 \mathrm{bp}$ from IR to LSC in the $V$. unguiculata. However, in C. cajan, G. $\max$ and G. soja, the rps19 gene crossed the IRb/LSC region, with 46, 68 and $68 \mathrm{bp}$ of rps 19 gene within IRb, respectively. On the other hand, the $y c f 1$ gene is located at the IRa/SSC border in all the compared legumes, but the junctions of IRa/SSC located in $y c f 1$ within the SSC and IRa regions vary in length $(P$. lunatus: 4706 and $616 \mathrm{bp} ; P$. vulgaris: 4775 and 505 bp; $V$. radiate: 4683 and 492 bp; $V$. unguiculata: 4683 and $492 \mathrm{bp}$; C. cajan: 13 and $473 \mathrm{bp}$; G.max: 11 and $478 \mathrm{bp}$; G. soja: 11 and $478 \mathrm{bp}$ ), while the $y c f 1$ gene was only at the IRb/SSC border of $P$. vulgaris, C. cajan, G. max, and G. soja and the size varies among them.

\section{Adaptive evaluation analysis}

The $\mathrm{Ka} / \mathrm{Ks}$ ratio were calculated by KaKs_Calculator among the Cp genome of eleven species of Leguminosae protein-coding genes. The results indicated that the $\mathrm{Ka} /$ Ks ratio is $<1$ in mostly except for rpl23 of $V$. faba vs $P$. lunatusis, $n d h D$ of C. cajan, rps18 of M. truncatula vs $P$.

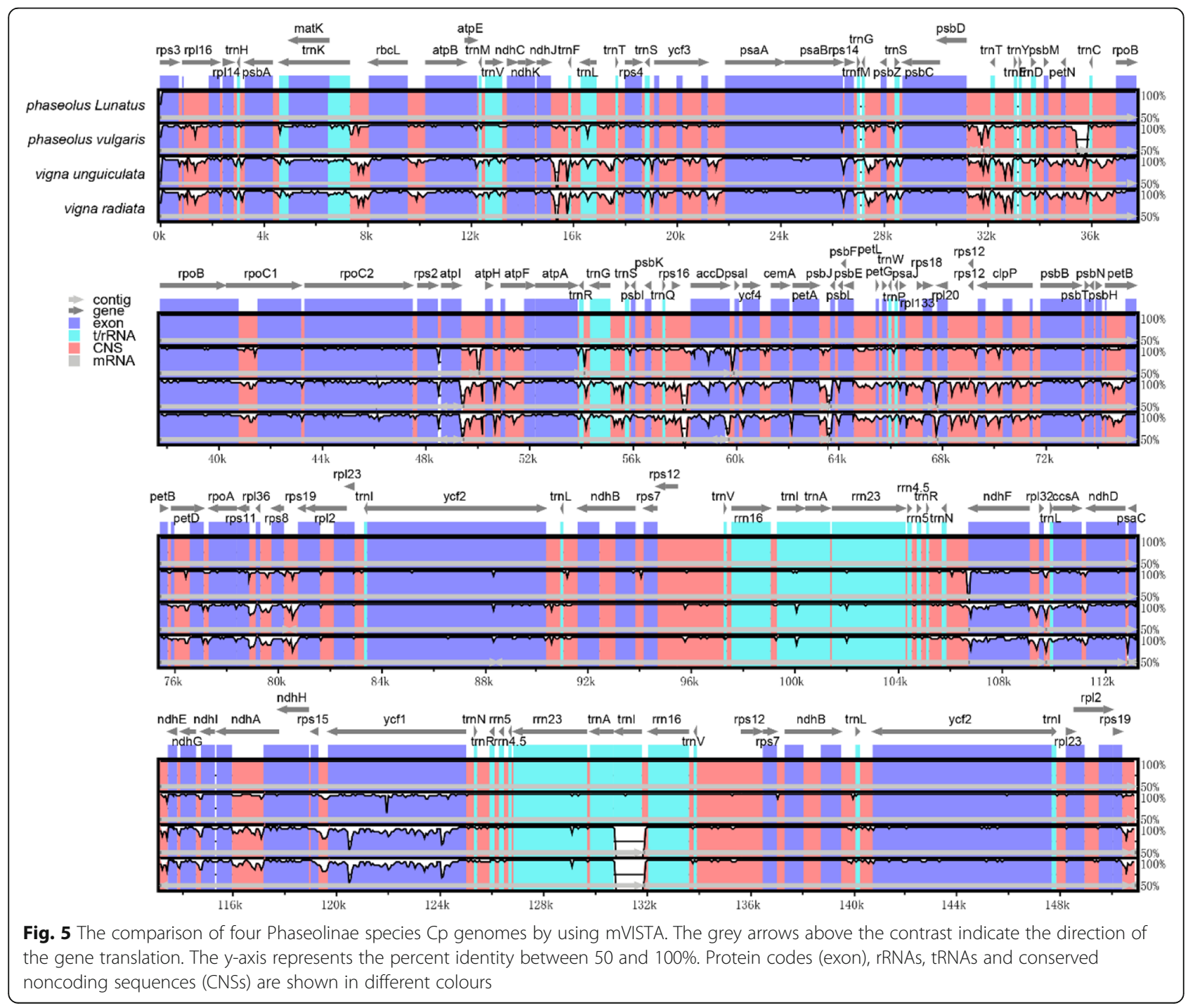




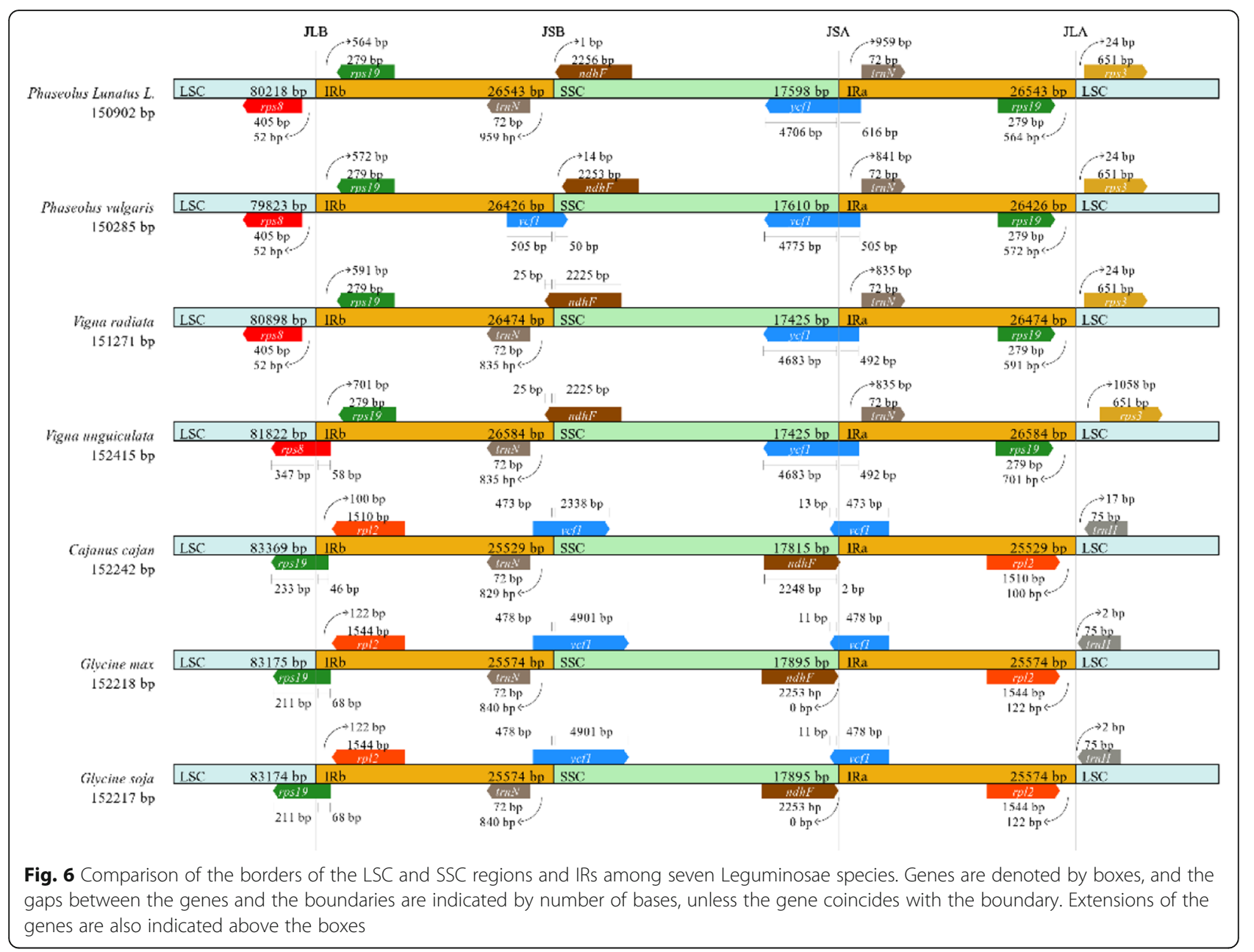

lunatusis, ndhD of G. max vs P. lunatusis, accD/ ycf2/ $n d h D$ of $P$. vulgaris vs $P$. lunatusis, $n d h B /$ rps $15 / n d h B$ of $C$. arietinum vs $P$. lunatusis, petL/ ycf2/ ndhD of $V$ radiata vs $P$. lunatusis, pet $L / y c f 2$ of $V$. unguiculata vs $P$. lunatusis (Fig. 7). For each gene, the majority had a Ka/ Ks ratio $<0.5$ for the ten comparison groups. At the same time, 13 of them had a $\mathrm{Ka} / \mathrm{Ks}$ ratio between 0 and
0.1 . In contrast, the $\mathrm{Ka} / \mathrm{Ks}$ ratio of the $n d h D$ gene was greater than 1 in four of the ten comparison groups, four of them had no this gene and another two exhibited low $\mathrm{Ka} / \mathrm{Ks}$ ratios. Moreover, $y c f 2$ also exhibited a $\mathrm{Ka} / \mathrm{Ks}$ ratios $>1$ in three of them and the ratio $>0.5$ in the other species.

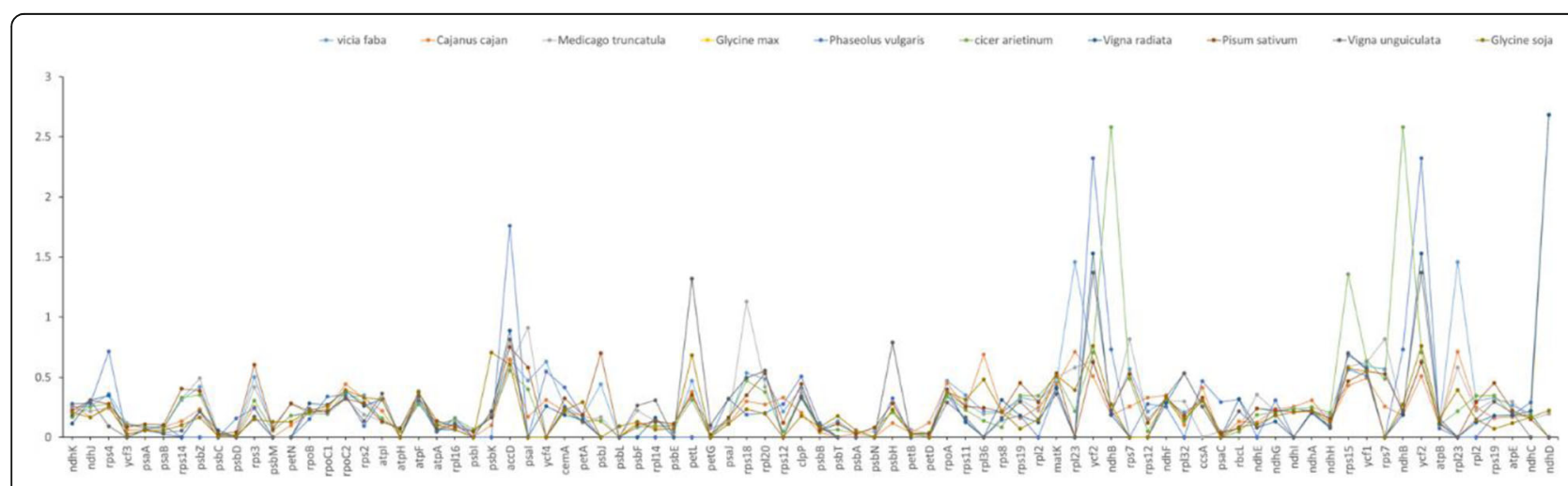

Fig. 7 The Ka/Ks ration values of 82 protein coding genes from ten Leguminosae cp genomes 


\section{Phylogenetic analysis}

To identified the phylogenetic position of lima bean in Leguminosae, we used the 44 protein sequences of 48 Leguminosae species to phylogenetic analyse (Fig. 8). Maximum likelihood (MI) and Bayesian inference (BI) were used to construct phylogenetic tree with Arabidopsis thaliana as outgroup. The phylogenetic results resolved most nodes with bootstrap support values of 100 . These 48 species belong to Caesalpinoideae, Cercidoideae, Detarioideae and Papilionoideae. The phylogenetic tree showed that $P$. lunatus and $P$. vulgaris are sister spisecies with a $100 \%$ bootstrap value and $P$. lunatusis more closely related to $P$. vulgaris, $V$. unguiculate and $V$. radiata. The phylogenetic trees are very helpful for us to understand the phylogenetic relationship among more Leguminosae species.

\section{Discussion}

In this study, the Cp genome of lima bean were sequenced and assembled, and this information was applied for their comparative analysis with other Leguminosae species. The size of genome, content of GC, the length of IR, LSC, and SSC regions and gene content exposed high similarity among the genomes, suggesting that leguminosae species shared low diversity $[20,21,37,38]$. The GC content is closely related to species affinity [39]. High GC content is conducive to the stability of the genome and maintaining the complexity of the sequence. The four rRNAs genes have high GC content, which results in a high GC content in the IR region [40]. The codon usage bias is related to translational efficiency, which biased towards rich tRNA. At the same time, those codons that bind more tightly than other homologous tRNAs [41]. In this study, all genes were encoded by 25,873 codons, in these codons the most frequent amino acids are leucine (2719, 10.51\%) and the least are cysteine (300, 1.16\%). The most preferred synonymous codons end with A and U. High AT abundance is the main cause why synonym codons end with $\mathrm{A} / \mathrm{U}$, which may be the result of natural selection and mutation $[42,43]$.

Repeat sequences are significant important for genome rearrangements and variations, and repeat occurrence is more prevalent in IGSs than in genic sequences [44-46]. Furthermore, these repeats can be used to develop genetic markers for phylogeny and population studies [47]. We found 61 repeat sequences in P. lunatus Cp genome, and most of the repeats were distributed within the intergenic spacer regions, intron sequences, and $y c f 2$ genes, which is highly homologous to the sequence in V.radiata [20].

Currently, chloroplast genome markers have more advantages than nuclear DNA markers in terms of evolution and taxonomic research due to their maternal inheritance in most plants and much lower mutation rate $[48,49]$. cpSSRs are often used to identify species and analyze genetic because they are relatively richness and have demonstrated high reproducibility and polymorphism. Two hundred ninety SSRs were found in the lima bean Cp genime. The number of SSR is similar to those in pigeonpea [37], but more than clusterbean [18]. Among 290 SSRs, most of them distributed in LSC $(63.45 \%)$ and located in intergenic spacers $(45.86 \%)$. The findings were similar to clusterbean [18] and pigeonpea [37].

Although the Cp genomes of angiosperms are wellconserved, inversion, rearrangement, novel DNA insertion and IR expansion contraction occur frequently [18, $21,25]$. Leguminosae is an excellent choice for studying the evolution of the $\mathrm{Cp}$ genome because legume plastid genomes have undergone multiple genomic rearrangements and the loss of genes or introns [50].. In our study, $P$. lunatus has a common $50 \mathrm{~kb}$ inversion in the LSC region, spanning from $r b c L$ to $r p s 16$, which has been found in other legumes (Fig. 4) [18, 20, 21]. Due to the expansion and contraction of IRs, the Cp genomes of $P$. vulgaris, $V$. radiata and $V$. unguicalata have $70 \mathrm{~kb}$ inversion to subtribe Phaseolinae but are absent from other Cp genomes [51, 52]. P. lunatus as a member of the subtribe Phaseolinae shows the same inversion. All the results shown in the gene order suggest that considerable rearrangements and diversification were occurred in the legume $\mathrm{Cp}$ genomes and a valuable resource for phylogenetic analysis is provided.

Crop evolution and genetic improvement progress mainly depends on the genetic diversity available in germplasm resources [53]. rpl16, accD, petB, rsp16, clpP, $n d h A, n d h F$ and $y c f 1$ genes in CDS was found significant variation and high sequence variations were found in intergenic regions as follows: $t r n k-r b c L, r b c L-a t p B, n d h J-$ rps4, psbD-rpoB, atpI-atpA, atpA-accD, accD-psbJ, psbEpsbB, rsp11-rsp19, ndhF-ccsA (Fig. 5). These regions were considered useful markers for elucidating phylogenetic relationships among Leguminosae species. The $y c f 1, a c c D$ and $n d h F$ genes were also served as genetic markers for Quercus bawanglingensis [54]. The Cp DNA regions: $\operatorname{trn} L-\operatorname{trn} F$ and $a t p B-r b c L$ were used to evaluate 262 accessions of $P$. lunatus to identify whether the MA gene pool of $P$. lunatus has a single centre or multiple centres [55]. trnL-trnF in noncoding Cp DNA regions also has been used to study Phylogeny and domestication [56-58]. polymorphisms of the Cp DNA is very useful to study the evolutionary of Lima bean and to pinpoint domestication places in several studies. Hence, more and more genome resources need to be developed for plants [59].

Studies have shown that IR regions in plant chloroplast genomes are more conserved than single copy and 


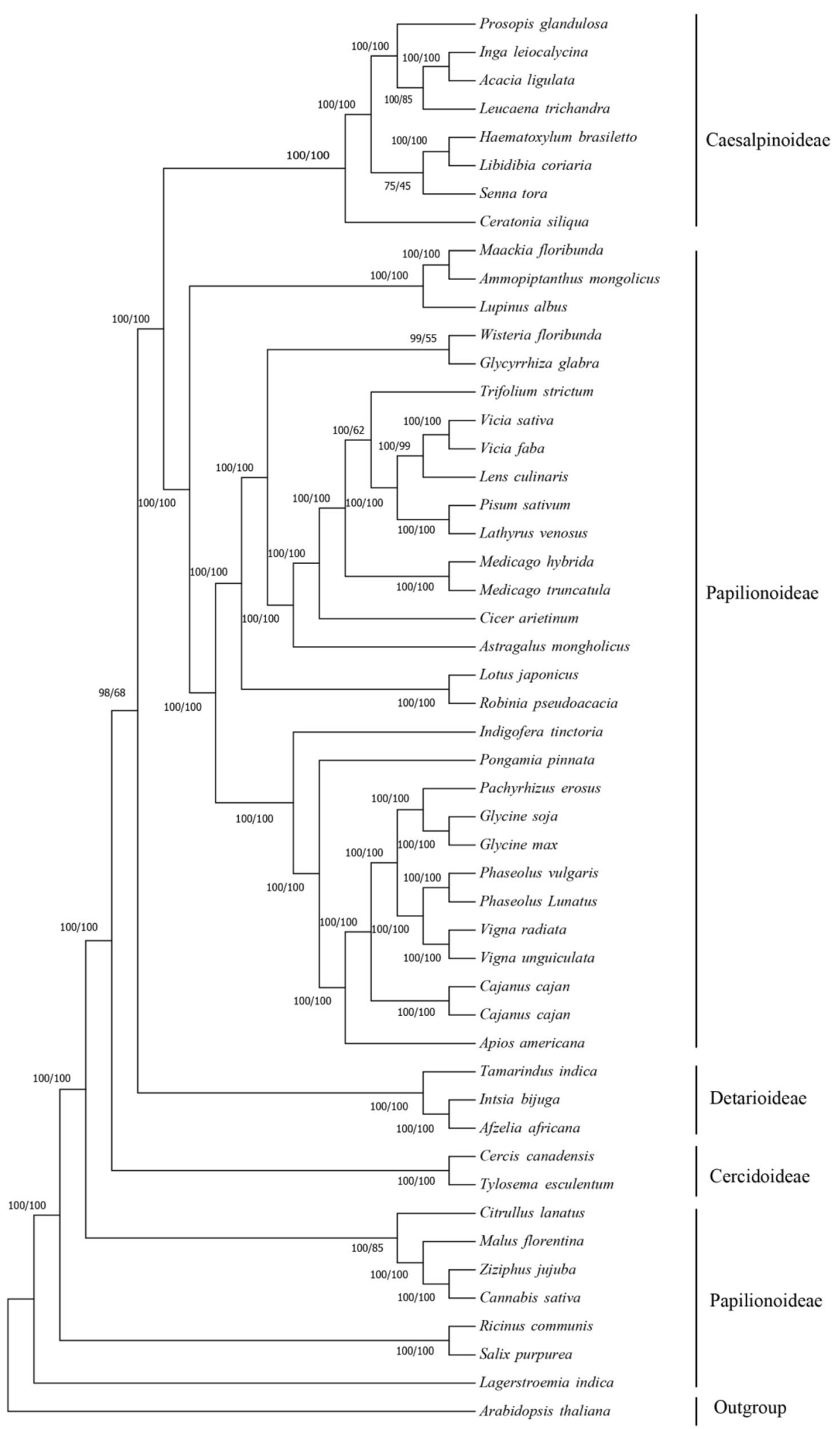

Fig. 8 Maximum likelihood (ML) and Bayesian Inference (BI) phylogenetic tree of 48 species of Leguminosae constructed using the sequences of 44 proteins. Arabidopsis thaliana were used as the outgroups 
non-coding regions, and can stable the rest genome [38]. The size change of the angiosperm plastid genome is caused by the contraction and expansion of the IR region at the boundary $[51,60]$. The change of the IR/SC junction is a common phenomenon and plays an important role in evolution $[54,61,62]$. In the seven Leguminosae species, $P$. lunatus, $P$. vulgars, $V$. radiate and $V$. unguiculata showed similar characteristics, only some genes including rps8, rps19, trnN, ndhF, ycf1 and rps3 showed a little difference; C. cajan, G.max, and G. soja showed more differences than other four species (Fig. 6). The complete trnH-rps19 cluster of P. lunatus, P. vulgars, $V$. radiata and $V$. unguiculata is present in IR regions, which is consistent with TYPE III [63].

Non-synonymous (Ka) and synonymous (Ks) substitutions and their ratios $(\mathrm{Ka} / \mathrm{Ks})$ have been used to assess the rate of gene divergence. The ratio of $\mathrm{Ka} / \mathrm{Ks}<1$ represents purifying selection, while the ratio $>1$ represents positive selection [64]. In most protein-coding genes, nucleotide substitutions of synonymous occur more frequently than non-synonymous [65]. In this study, the ratio is $<1$ in most of the genes, indicating that they are under purifying selection in lima bean. However, the Ka/ Ks ratio of $n d h D$ gene is $>1$ in four of the ten comparison groups, $y c f 2$ exhibited a ratios $>1$ in three of them and the ratio $>0.5$ in the other species. The $n d h D$ and $y c f 2$ undergo positive selection in lima bean, which may help to adapt to their living environment.

Genetic analysis of lima bean was performed using cytogenetic [66] and molecular data [55]. With the development of sequencing technologies, an increasing number of $\mathrm{Cp}$ genomes have been used for phylogenetic analysis [35, 36]. The Cp genomes have been used for phylogenetic analyses in the genus Quercus, which provide strong support for the deep phylogenetic relationship between subfamily tribes [67].. In our study, the sequences of chloroplast genomes were used for phylogenetic analysis by ML and BI based on 48 Leguminosae species. $P$. vulgaris and $P$. lunatus are sister species, $P$. lunatus is more closely related to $P$. vulgaris, $V$. unguiculata and V. radiata. Consistent with the gene order results, they are all of subtribe Phaseolinae. The result is consistent with other phylogenies constructed by $\mathrm{Cp}$ genome containing representatives Phaseolinae genus [68-70].

\section{Conclusions}

In this study, the complete Cp genome of P.lunatus was first sequenced on IlluminaNextera XT platforms. The size of genome, structure and organization of gene were shown to be conservative, which is similar to those reported Cp genomes of Leguminosae species. Sixty-one repeats and 290 SSRs were present in P. lunatus. These results are very useful for developing barcoding molecular markers. In comparison with other legume species, the Cp genome of lima bean shares a similar gene order and IR region borders with $P$. vulgaris, $V$. unguiculata and $V$. radiata. Phylogenetic analysis of 48 Leguminosae species shows that $P$. lunatus are more closely related to $P$. vulgaris, $V$. unguiculata and $V$. radiata. These results provide important information for the complete Cp genome of $P$. lunatus, which might be useful for further studies of evolution and phylogenetic.

\section{Methods}

Sequencing and assembly of lima bean $\mathrm{Cp}$ genome

Fresh leaves were collected from lima bean plants grown on Huiyuan Vegetable Gardening Farm at Chongming Island [6]. Genomic DNA was extracted by CTAB method [71]. Then the DNA quality was tested $(>50$ ng. $\mu \mathrm{L}-1)$. The DNA was sequenced by the $\mathrm{HiSeq}^{\mathrm{ma}} \mathrm{X} 10$ platform (Illumina, USA) at Nanjing. Bowtie2 v2.2.4 [72] was used to exclude non-chloroplast genome reads with paired-end alignments and a maximum of 3 mismatches $(-\mathrm{v}=3)$, as the raw sequence reads always include non-cpDNA. The Cp genome was assembled by SPAdesv3.10.1 [73] and with the options of "-trusted-contigs" via manual correction using comparison with the reference species $P$. vulgaris (NCBI ACCESSION NC_ 009259.1). The Cp genome of lima bean was submitted into GenBank (SRA: SRR13319750, BioProject: PRJNA688003 Accession number: MW423611).

\section{Genome annotation of the cp DNA sequences}

The annotation of the Lima bean Cp genome was performed by blast v2.2.2 (parameter: -nproc 20, -bestn 5 [74]., and the final annotation result was correct manually. rRNAs and tRNAs were identified by hmmer v3.1b2 [75] and aragorn v1.2.38 [76], respectively. The entire genome was mapped by OGDRAW [77]. The synonymous codon usage, relative synonymous codon usage values (RSCU) and codon usage of the complete plastid genomes were analyzed using MEGA 6.0 PREP suit [78] with cut off values of 8.0 was used to predict the RNA editing sites in the plastome.

\section{Characterization of repeat sequences and SSRs}

Interspersed repeated sequences were detected by Vmatch v2.3.0 [79]. Simple sequence repeats (SSRs) were identified by MISA v1.0 [80].

\section{Comparative analysis of $\mathrm{Cp}$ genomes}

MUMmer was used to pair sequence alignment of the chloroplast genome [81]. The chloroplast genome of $P$. lunatus (SRA: SRR13319750, BioProject: PRJNA688003) was compared with $P$. vulgaris (NC_009259), V. radiate (NC_013843) and $V$. unguiculata (NC_018051) in the Leguminosae tribe by mVISTA with the shuffle-LAGAN 
mode $[82,83]$. The annotation of $P$. lunatus was set as a reference.

The gene order comparison was performed by MAUVE [84] between lima bean (SRA: SRR13319750, BioProject: PRJNA688003), Arabidopsis thaliana (NC_ 000932), C. cajan (KU729879), G. max (NC_007942), P. vulgaris (NC_009259), C. arietinum (NC_011163), V. radiate (NC_013843), G. soja (NC_022868), V. unguiculata (NC_018051) and M. truncatula (NC_003119).

\section{Adaptive evaluation analysis}

In order to analyze non-synonymous (Ka) and synonymous (Ks) substitution rates and $\mathrm{Ka} / \mathrm{Ks}$ ratio, P. lunatus was compared with the ten other species in Leguminosae tribe: G. $\max , C$. cajan, C. arietinum, $V$. radiate, $P$. vulgaris, G. soja, $V$. unguiculata, $P$. sativum, $V$. faba and M. truncatula. The ten sequences was separately aligned by MAFFT v7.427 [85], then the Ka and Ks substitution rates and $\mathrm{Ka} / \mathrm{Ks}$ value was counted using the KaKs_calculator 2.0 [86] with the default model averaging (MA) method.

\section{Phylogenetic analysis}

The phylogenetic analysis was conducted for lima bean, another 47 Leguminosae species, and one outgroup Arabidopsis thaliana, all of which were down loaded from the NCBI except those of $P$. lunatus. The complete $C p$ genomes were aligned using MAFFT v7.427 [85]. RAxML v.8.2.10 [87] and MrBayes version 3.2.6 [88] was used to reconstruct the phylogenetic relationship with the maximum likelihood (ML) and Bayesian Inference (BI) methods.

\section{Availability of data and materials}

The $\mathrm{Cp}$ genome of $P$. lunatus were uploaded to the NCBI database (https://www.ncbi.nlm.nih.gov/) with GenBank accession numbers (SRA: SRR13319750, BioProject: PRJNA688003). Other data can be obtained by contacting the corresponding author.

\section{Abbreviations}

CNS: Conserved non coding sequence; Cp: Chloroplast:

DNA: Deoxyribonucleic acid; IGS: Intergenic spacer; IR: Inverted repeat; LSC: Large single copy region; RSCU: Relative synonymous codon usage; SSC: Small single copy region; SSR: Simple sequence repeats; Ka: Nonsynonymous; Ks: synonymous

\section{Supplementary Information}

The online version contains supplementary material available at https:/doi. org/10.1186/s12864-021-07467-8.

Additional file 1: Table S1. The number of genes in the P. lunatus Cp genome.

Additional file 2: Table S2. The relative synonymous codon usage of the $P$. lunatus chloroplast genome.
Additional file 3: Table S3. Repeated sequences of the P. lunatus chloroplast genome.

Additional file 4: Table S4. Simple sequence repeats (SSRs) in the $P$. lunatus chloroplast genome.

\section{Acknowledgments}

We are grateful to J.W. for revised the manuscript and reviewers for their valuable comments on the manuscript.

\section{Authors' contributions}

$\mathrm{PL}$ and ST analyzed the date and wrote the manuscript. ST performed the experiments. HZ, JW and ZZ involved in interpretation of data and revised the manuscript. HS involved in designing the research and revised the manuscript. All authors read and approved the manuscript.

\section{Funding}

This work was financed by Shanghai Grants from the SAAS Program for Excellent Research Team (2017 (B-06)), China Agriculture Research System (Grant No. CARS-25). The funding bodies did not play a role in the design of the study and collection, analysis, and interpretation of data and in writing the manuscript.

\section{Availability of data and materials}

The datasets supporting the results of this publication are included within the article and Additional files 1, 2, 3, 4.

\section{Declarations}

Ethics approval and consent to participate

Not applicable. The plant was collected in non protected area; no any legal authorization/license is required.

Consent for publication

Not applicable.

\section{Competing interests}

The authors declare that they have no competing interest.

\section{Author details}

${ }^{1}$ Shanghai Key Laboratory of Protected Horticultural Technology, Horticultural Research Institute, Shanghai Academy of Agricultural Sciences, Shanghai 201403, China. ${ }^{2}$ Nanjing Agricultural University, NanJing 210095, China.

Received: 17 November 2020 Accepted: 23 February 2021

Published online: 18 March 2021

\section{References}

1. Jean-pierre Baudoin OR, Degreef J, Maquet A, Guarino L. Ecogeography, demography, diversity and conservation of Phaseolus lunatus L. in the central valley of Costa Rica. Systematic \& Ecogeographic Studies on Crop Genepools. 2004. p. 1-94.

2. Almeida C, Pedrosa-Harand A. High macro-collinearity between lima bean (Phaseolus lunatus L.) and the common bean (P. vulgaris L.) as revealed by comparative cytogenetic mapping. Theor Appl Genet. 2013;126(7):1909-16.

3. Chacon-Sanchez Ml, Martinez-Castillo J. Testing Domestication Scenarios of Lima Bean (Phaseolus lunatus L.) in Mesoamerica: Insights from GenomeWide Genetic Markers. Front Plant Sci. 2017;8:1551.

4. Bi IZ, Maquet A, Baudoin JP. Population genetic structure of wild Phaseolus lunatus (Fabaceae), with special reference to population sizes. Am J Bot. 2003;90:897.

5. Zoro BI, Maquet A, Degreef J, Wathelet BJP. BaudoinSample size for collecting seeds in germplasm conservation: the case of the Lima bean (Phaseolus lunatus L.). Theor Appl Genet. 1998;97(1-2):187-94.

6. Rong-Fei MA, Fan-Lei M, Li-Jun GU. Cluster analysis and evaluationon germplasm resources of Chongming lima bean. Acta Agriculturae Shanghai. 2013;29:114

7. Rono PC, Dong X, Yang JX, Mutie FM, Oulo MA, Malombe I, Kirika PM, Hu GW, Wang QF. Initial complete chloroplast genomes of Alchemilla (Rosaceae): comparative analysis and phylogenetic relationships. Front Genet. 2020;11:560368. 
8. Jansen RK, Wojciechowski MF, Sanniyasi E, Lee SB, Daniell H. Complete plastid genome sequence of the chickpea (Cicer arietinum) and the phylogenetic distribution of rps 12 and clpP intron losses among legumes (Leguminosae). Mol Phylogenet Evol. 2008;48(3):1204-17.

9. Yue F, Cui L, Depamphilis CW, Moret BME, Tang J. Gene rearrangement analysis and ancestral order inference from chloroplast genomes with inverted repeat. BMC Genomics. 2008;9(Suppl 1):S25.

10. Aldrich J, Cherney B, Merlin E, Williams C, Mets L. Recombination within the inverted repeat sequences of the Chlamydomonas reinhardii chloroplast genome produces two orientation isomers. Curr Genet. 1985:9(3):233-8.

11. Aldrich J, Cherney BW, Williams C, Merlin E. Sequence-analysis of the junction of the large single copy region and the large inverted repeat in the petunia chloroplast genome. Curr Genet. 1988;14(5):487-92.

12. Chang CC, Lin HC, Lin IP, Chow TY, Chen HH, Chen WH, Cheng CH, Lin CY, Liu SM, Chang CC, et al. The chloroplast genome of Phalaenopsis aphrodite (Orchidaceae): comparative analysis of evolutionary rate with that of grasses and its phylogenetic implications. Mol Biol Evol. 2006;23(2):279-91.

13. Jansen RK. Extreme reconfiguration of plastid genomes in the angiosperm family Geraniaceae: rearrangements, repeats, and codon usage. Mol Biol Evol. 2011;28(1):583-600.

14. Huang S, Ge X, Cano A, Salazar BGM, Deng Y. Comparative analysis of chloroplast genomes for five Dicliptera species (Acanthaceae): molecular structure, phylogenetic relationships, and adaptive evolution. PeerJ. 2020; 8(1):e8450.

15. Azani N, Babineau M, Bailey CD, Banks $H$, Barbosa AR, Pinto RB, Boatwright JS, Borges LM, Brown GK, Bruneau A et al. A new subfamily classification of the Leguminosae based on a taxonomically comprehensive phylogeny. Taxon. 2017:66(1):44-77.

16. Gao CW, Gao LZ. The complete chloroplast genome sequence of semi-wild soybean, Glycine gracilis (Fabales: Fabaceae). Conserv Genet Resour. 2017; 9(2):343-5.

17. Tomohiko K, Takakazu K, Shusei S, Yasukazu N, Satoshi T. Complete Structure of the Chloroplast Genome of a Legume, Lotus japonicus. DNA Research 2000;7:323-30.

18. Kaila T, Chaduvla PK, Rawal HC, Saxena S, Tyagi A, Mithra SVA, Solanke AU, Kalia P, Sharma TR, Singh NK, et al. Chloroplast Genome Sequence of Clusterbean (Cyamopsis tetragonoloba L.): Genome Structure and Comparative Analysis. Genes. 2017:8(9):212.

19. Saski C, Lee SB, Daniell H, Wood TC, Tomkins J, Kim HG, Jansen RK. Complete chloroplast genome sequence of Glycine max and comparative analyses with other legume genomes. Plant Mol Biol. 2005;59(2):309-22.

20. Tangphatsornruang S, Sangsrakru D, Chanprasert J, Uthaipaisanwong P, Yoocha T, Jomchai N, Tragoonrung S. The Chloroplast Genome Sequence of Mungbean (Vigna radiata) Determined by High-throughput Pyrosequencing: Structural Organization and Phylogenetic Relationships. DNA Research. 2009;17(1):11-22.

21. Guo XW, Castillo-Ramirez S, Gonzalez V, Bustos P, Fernandez-Vazquez JL, Santamaria RI, Arellano J, Cevallos MA, Davila G. Rapid evolutionary change of common bean (Phaseolus vulgaris L) plastome, and the genomic diversification of legume chloroplasts. BMC Genomics. 2007;8:16

22. Lavin M, Herendeen PS, Wojciechowski MF, Lavin M, Herendeen PS, Wojciechowski MF. Evolutionary rates analysis of Leguminosae implicates a rapid diversification of lineages during the tertiary. Syst biol 54: 530-549. Syst Biol. 2005;54(4):575-94.

23. Palmer JD, Thompson WF. Chloroplast DNA rearrangements are more frequent when a large inverted repeat sequence is lost. Cell. 1982;29(2):537-50

24. Lavin M, Doyle JJ, Palmer JD. EVOLUTIONARY SIGNIFICANCE OF THE LOSS OF THE CHLOROPLAST-DNA INVERTED REPEAT IN THE LEGUMINOSAE SUBFAMILY PAPILIONOIDEAE. Evolution. 1990:44(2):390.

25. Cai ZQ, Guisinger M, Kim HG, Ruck E, Blazier JC, McMurtry V, Kuehl JV, Boore $J$, Jansen RK. Extensive reorganization of the plastid genome of Trifolium subterraneum (Fabaceae) is associated with numerous repeated sequences and novel DNA insertions. J Mol Evol. 2008;67(6):696-704

26. Doyle JJ, Doyle JL, Palmer JD. Multiple independent losses of two genes and one intron from legume chloroplast genomes. Syst Bot. 1995;20(3):272-94.

27. Gantt JS, Baldauf SL, Calie PJ, Weeden NF, Palmer JD. Transfer of rpl22 to the nucleus greatly preceded its loss from the chloroplast and involved the gain of an intron. EMBO J. 1991;10(10):3073-8.

28. Magee AM, Aspinall S, Rice DW, Cusack BP, Semon M, Perry AS, Stefanovic S, Milbourne D, Barth S, Palmer JD. Localized hypermutation and associated gene losses in legume chloroplast genomes. Genome Res. 2010;20(12):1700-10.
29. Moore MJ, Soltis PS, Bell CD, Burleigh JG, Soltis DE. Phylogenetic analysis of 83 plastid genes further resolves the early diversification of eudicots. Proc Natl Acad Sci U S A. 2010;107(10):4623-8.

30. Dan Z, Kui L, Ju G, Yuan L, Li-Zhi G. The complete plastid genome sequence of the wild Rice Zizania latifolia and comparative chloroplast genomics of the Rice tribe Oryzeae, Poaceae. Front Ecol Evol. 2016;4:88.

31. Osuna-Mascaró C, Rafael RDC, Perfectti F. Comparative assessment shows the reliability of chloroplast genome assembly using RNA-seq. Sci Rep. 2018; 8(1):17404.

32. Käss E, Wink M. Phylogenetic relationships in the Papilionoideae (family Leguminosae) based on nucleotide sequences of cpDNA (rbcL) and ncDNA (ITS 1 and 2). Mol Phylogenet Evol. 1997;8(1):65-88.

33. Brouat C, Gielly L, McKey D. Phylogenetic relationships in the genus Leonardoxa (Leguminosae: Caesalpinioideae) inferred from chloroplast trnL intron and trnL-trnF intergenic spacer sequences. Am J Bot. 2001;88(1):143-9.

34. Manzanilla V, Bruneau A. Phylogeny reconstruction in the Caesalpinieae grade (Leguminosae) based on duplicated copies of the sucrose synthase gene and plastid markers. Mol Phylogenet Evol. 2012;65(1):149-62.

35. Alzahrani DA, Yaradua SS, Albokhari EJ, Abba A. Complete chloroplast genome sequence of Barleria prionitis, comparative chloroplast genomics and phylogenetic relationships among Acanthoideae. BMC Genomics. 2020; 21(1):393.

36. Lemieux C, Otis C, Turmel M. Comparative chloroplast genome analyses of Streptophyte Green algae uncover major structural alterations in the Klebsormidiophyceae, Coleochaetophyceae and Zygnematophyceae. Front Plant Sci. 2016;7:697.

37. Kaila T, Chaduvla PK, Saxena S, Bahadur K, Gahukar SJ, Chaudhury A, Sharma TR, Singh NK, Gaikwad K. Chloroplast Genome Sequence of Pigeonpea (Cajanus cajan (L.) Millspaugh) and Cajanus scarabaeoides (L.) Thouars: Genome Organization and Comparison with Other Legumes. Front Plant Sci. 2016;7:1847.

38. Kaila T, Chaduvla PK, Saxena S, Bahadur K, Gahukar SJ, Chaudhury A, Sharma TR, Singh NK, Gaikwad K. Chloroplast Genome Sequence of Pigeonpea (Cajanus cajan (L.) Millspaugh) and Cajanus scarabaeoides (L.) Thouars: Genome Organization and Comparison with Other Legumes. Front Plant Sci. 2016;7:1847.

39. Budhi DA, Yohei T, Sri S, Arifin ZMS, Toyoko A, Yoko S, Petr H. The origin and evolution of fibromelanosis in domesticated chickens: genomic comparison of Indonesian Cemani and Chinese Silkie breeds. PLoS One. 2017;12(4):e0173147.

40. Kaila T, Chaduvla PK, Saxena S, Bahadur K, Gahukar SJ, Chaudhury A, Sharma TR, Singh NK, Gaikwad K. Chloroplast Genome Sequence of Pigeonpea (Cajanus cajan (L.) Millspaugh) and Cajanus scarabaeoides (L.) Thouars: Genome Organization and Comparison with Other Legumes. Front Plant Sci. 2016;7:1847.

41. Salim HMW, Cavalcanti ARO. Factors influencing codon usage bias in genomes. J Braz Chem Soc. 2008;19(2):257.

42. Necşulea A, Lobry JR. A new method for assessing the effect of replication on DNA base composition asymmetry. Mol Biol Evol. 2007;24(10):2169-79.

43. Shimada $H$, Sugiura M. Fine structural features of the chloroplast genome: comparison of the sequenced chloroplast genomes. Nucleic Acids Res. 1991;19(5):983-95.

44. Yan C, Du J, Gao L, Li Y, Hou X. The complete chloroplast genome sequence of watercress (Nasturtium officinale R. Br.): Genome organization, adaptive evolution and phylogenetic relationships in Cardamineae. Gene. 2019;699:24.

45. Su-Young H, Kyeong-Sik C, Ki-Oug Y, Hyun-Oh L, Kwang-Soo C, Jong-Taek S, Su-Jeong K, Jeong-Hwan N, Hwang-Bae S, Yul-Ho K. Complete Chloroplast Genome Sequences and Comparative Analysis of Chenopodium quinoa and C album. Front Plant Sci. 2017:8:1696.

46. Huang YY, Matzke AJM, Matzke M. Complete sequence and comparative analysis of the chloroplast genome of coconut palm (Cocos nucifera). PLoS One. 2013;8:e74736

47. Sajjad A, Muhammad W, Khan AL, Khan MA, Kang SM, Imran QM, Raheem S, Saqib B, Yun BW, In-Jung L. The complete chloroplast genome of wild Rice (Oryza minuta) and its comparison to related species; 2017.

48. Holwerda BC, Jana S, Crosby WL. Chloroplast and mitochondrial DNA variation in HORDEUM VULGARE and HORDEUM SPONTANEUM. Genetics. 1986;114(4):1271.

49. Vanichanon A, Blake N, Sherman J, Talbert L. Multiple origins of allopolyploid Aegilops triuncialis. Theor Appl Genet. 2003;106(5):804-10. 
50. Jansen RK, Cai Z, Raubeson LA, Daniell H, Depamphilis CW, Leebens-Mack J, Muller KF, Guisinger-Bellian M, Haberle RC, Hansen AK, et al. Analysis of 81 genes from 64 plastid genomes resolves relationships in angiosperms and identifies genome-scale evolutionary patterns. Proc Natl Acad Sci U S A. 2007;104(49):19369-74.

51. Tanvi K, Chaduvla PK, Swati S, Kaushlendra B, Gahukar SJ, Ashok C, Sharma TR, Singh NK, Kishor G. Chloroplast Genome Sequence of Pigeonpea (Cajanus cajan (L.) Millspaugh) and Cajanus scarabaeoides (L.) Thouars: Genome Organization and Comparison with Other Legumes. Front Plant Sci. 2016:7:1847.

52. Bruneau A, Palmer DJD. A chloroplast DNA inversion as a subtribal character in the Phaseoleae (Leguminosae). Syst Bot. 1990;15(3):378-86.

53. Baudoin JP. Genetic resources, domestication and evolution of lima bean, Phaseolus lunatus. J Emerg Med. 1988;39(2):253-60.

54. Liu X, Chang E-M, Liu J-F, Huang Y-N, Wang Y, Yao N, Jiang Z-P. Complete Chloroplast Genome Sequence and Phylogenetic Analysis of Quercus bawanglingensis Huang, Li et Xing, a Vulnerable Oak Tree in China. Forests. 2019;10(7):587

55. Andueza-Noh RH, Serrano-Serrano ML, Sánchez MC, Del Pino IS, CamachoPérez L, Coello-Coello J, Cortes JM, Debouck DG, Martínez-Castillo J. Multiple domestications of the Mesoamerican gene pool of lima bean (Phaseolus lunatus L.): evidence from chloroplast DNA sequences. Genetic Resour Crop Evol. 2013;60(3):1069-86

56. Taberlet P, Gielly L, Pautou G, Bouvet J. Universal primers for amplification of three non-coding regions of chloroplast DNA. Plant Mol Biol. 1991;17(5):1105-9.

57. Shaw J, Lickey EB, Beck JT, Farmer SB, Liu WS, Miller J, Siripun KC, Winder $C T$, Schilling EE, Small RL. The tortoise and the hare II: relative utility of 21 noncoding chloroplast DNA sequences for phylogenetic analysis. Am J Bot. 2005;92(1):142-66.

58. Shaw J, Lickey EB, Schilling EE, Small RL. Comparison of whole chloroplast genome sequences to choose noncoding regions for phylogenetic studies in angiosperms: the tortoise and the hare III. Am J Bot. 2007;94(3):275-88.

59. Sánchez MIC. Organelle genomes in Phaseolus beans and their use in evolutionary studies; 2017.

60. Xiaohong Y. The first complete chloroplast genome sequences in Actinidiaceae: genome structure and comparative analysis. PLoS One. 2015; 10(10):e0129347

61. Davis Jl, Soreng RJ. Migration of endpoints of two genes relative to boundaries between regions of the plastid genome in the grass family (POACEAE). Am J Bot. 2010;97(5):874-92.

62. Huo YM, Gao LM, Liu BJ, Yang YY, Wu X. Complete chloroplast genome sequences of four Allium species: comparative and phylogenetic analyses. Sci Rep. 2019:9(1):1-14.

63. Wang RJ, Cheng CL, Chang CC, Wu CL, Su TM, Chaw SM. Dynamics and evolution of the inverted repeat-large single copy junctions in the chloroplast genomes of monocots. BMC Evol Biol. 2008;8:14.

64. Yang Z, Nielsen R. Estimating synonymous and nonsynonymous substitution rates under realistic evolutionary models. Mol Biol Evol. 2000; 17(1):32-43.

65. Makalowski W, Boguski MS. Evolutionary parameters of the transcribed mammalian genome: an analysis of 2,820 orthologous rodent and human sequences. Proc Natl Acad Sci U S A. 1998;95(16):9407-12.

66. Bonifácio EM, Fonsêca A, Almeida C, Santos KGBD, Pedrosa-Harand A Comparative cytogenetic mapping between the lima bean (Phaseolus lunatus L.) and the common bean (P. vulgaris L.). Theor Appl Genet. 2012; 124(8):1513-20.

67. Xuan L, Yongfu L, Mingyue Z, Mingzhi L, Yanming F. Complete Chloroplast Genome Sequence and Phylogenetic Analysis of Quercus acutissima. Int J Mol Sci. 2018:19(8):2443.

68. Zha X, Wang X, Li J, Gao F, Zhou Y. Complete chloroplast genome of Sophora alopecuroides (Papilionoideae): molecular structures, comparative genome analysis and phylogenetic analysis. J Genet. 2020;99:13.

69. Antunes AM, Soares TN, Targueta CP, Novaes E, Telles MP. The chloroplast genome sequence of Dipteryx alata Vog. (Fabaceae: Papilionoideae): genomic features and comparative analysis with other legume genomes. Brazilian J Bot. 2020:43:271-82

70. Deng CY, Xin GL, Zhang JQ, Zhao DM. Characterization of the complete chloroplast genome of Dalbergia hainanensis (Leguminosae), a vulnerably endangered legume endemic to China. Conserv Genet Resour. 2019;11:105-8.

71. Doyle J. A rapid DNA isolation procedure for small quantities of fresh leaf tissue. Phytochem Bull. 1987;19:11-5.
72. Langmead B, Salzberg SL. Fast gapped-read alignment with Bowtie 2. Nat Methods. 2012;9(4):357-9.

73. Bankevich A, Nurk S, Antipov D, Gurevich AA, Dvorkin M, Kulikov AS, Lesin VM, Nikolenko SI, Pham S, Prjibelski AD, et al. SPAdes: a new genome assembly algorithm and its applications to single-cell sequencing. J Comput Biol. 2012;19(5):455-77.

74. Christiam Camacho GC, Avagyan V, Ma N, Papadopoulos J, Bealer K, Madden TL. BLAST+: architecture and applications. BMC Bioinformatics. 2009:10:421.

75. Eddy SR, Eddy S. HMMER: biosequence analysis using profile hidden Markov models; 2015

76. Nelson MJ, Dang Y, Filek E, Zhang Z, Yu WWC, Ishida Kl, Green BR. Identification and transcription of transfer RNA genes in dinoflagellate plastid minicircles. Gene. 2007;392(1-2):291-8.

77. Lohse M, Drechsel O, Bock R. OrganellarGenomeDRAW (OGDRAW): a tool for the easy generation of high-quality custom graphical maps of plastid and mitochondrial genomes. Curr Genet. 2007;52(5-6):267-74.

78. Kurtz S, Choudhuri JV, Ohlebusch E, Schleiermacher C, Stoye J, Giegerich R. REPuter: the manifold applications of repeat analysis on a genomic scale. Nucleic Acids Res. 2001:29(22):4633-42.

79. Kurtz S. The Vmatch large scale sequence analysis software-a manual. Center Bioinformatics. 2010;170(24):391-2

80. Thiel T, Michalek W, Varshney RK, Graner A. Exploiting EST databases for the development and characterization of gene-derived SSR-markers in barley ( Hordeum vulgare L.). Theor Appl Genet. 2003;106(3):411-22.

81. Kurtz S, Phillippy AM, Delcher AL, Smoot ME, Shumway M, Antonescu C, Salzberg SL. Versatile and open software for comparing large genomes. Genome Biol. 2004:5(2):1-9.

82. Mayor C, Brudno M, Schwartz JR, Poliakov A, Rubin EM, Frazer KA, Pachter L, Dubchak I. VISTA : visualizing global DNA sequence alignments of arbitrary length. Bioinformatics. 2000;16(11):1046-7.

83. Frazer KA, Pachter L, Poliakov A, Rubin EM, Dubchak I. VISTA: computational tools for comparative genomics. Nucleic Acids Res. 2004:32:273-9.

84. Darling AE, Mau B, Blattner FR, Perna NT. Mauve: multiple alignment of conserved genomic sequence with rearrangements. Genome Res. 2004 14(7):1394-403.

85. Katoh K, Standley DM. MAFFT multiple sequence alignment software version 7: improvements in performance and usability. Mol Biol Evol. 2013; 30(4):772-80.

86. Wang D, Zhang Y, Zhang Z, Zhu J, Yu J. KaKs_Calculator 2.0: a toolkit incorporating gamma-series methods and sliding window strategies. Genomics Proteomics Bioinformatics. 2010:8(1):77-80.

87. Stamatakis A. RAxML version 8: a tool for phylogenetic analysis and postanalysis of large phylogenies. Bioinformatics. 2014;30(9):1312-3.

88. Ronquist F, Teslenko M, van der Mark P, Ayres DL, Darling A, Höhna S, Larget B, Liu L, Suchard MA, Huelsenbeck JP. MrBayes 3.2: efficient Bayesian phylogenetic inference and model choice across a large model space. Syst Biol. 2012;61(3):539-42.

\section{Publisher's Note}

Springer Nature remains neutral with regard to jurisdictional claims in published maps and institutional affiliations.

Ready to submit your research? Choose BMC and benefit from:

- fast, convenient online submission

- thorough peer review by experienced researchers in your field

- rapid publication on acceptance

- support for research data, including large and complex data types

- gold Open Access which fosters wider collaboration and increased citations

- maximum visibility for your research: over $100 \mathrm{M}$ website views per year

At BMC, research is always in progress.

Learn more biomedcentral.com/submission 